\title{
CORPORATE SOCIAL RESPONSIBILITY THROUGH THE EXAMPLE OF WANHUA-BORSODCHEM ZRT.
}

\author{
Alexandra Kulcsár \\ Ph.D. student, University of Miskolc \\ 3515 Miskolc, Miskolc-Egyetemváros, e-mail: kulcsar.alexandra@uni-miskolc.hu
}

\begin{abstract}
By 2012, BorsodChem, a well-known chemical plant in Northern Hungary was acquired by Wanhua Industrial Group making the largest investment in Europe. Wanhua is listed among the top 500 enterprises in China and by the end of 2019 its net assets reached 42 billion CNY. At the peak of globalization, it is becoming a high priority especially for multinational enterprises to direct from profit driven strategy towards becoming corporate citizens, and handling the responsibilities required, expected, and desired by society. You cannot put the same shoe on every foot, proves to be true to companies with different fields and backgrounds, that is each company needs to clarify their corporate culture, and aims for the sake of sustainability. The strategy and philosophical background behind the corporate social responsibility (CSR) of Chinese-owned enterprises differ from the Western standards and focus to follow the teachings of Confucius, creating a unique CSR with Chinese characteristics. This article aims to show some insight into a part of the CSR strategy of Wanhua.
\end{abstract}

Keywords: Chinese companies, corporate social responsibility, CSR, social development, Confucius

\section{Introduction}

The Hungarian governments after the turn of the millennium put the opening to the East in the forefront again and tried to position Hungary as China's gateway to the European Union. For this reason, they developed and supported the export and appearance of domestic enterprises in China, as well as the investments of Chinese companies and the establishment of Chinese investors in Hungary.

There are currently hundreds of Chinese-owned companies operating in Hungary, representing several sectors and forms; mainly in the field of hospitality and retail. The largest Chinese investment to date in Hungary took place during the acquisition of BorsodChem in Kazincbarcika in 2011. The transaction was carried out by Wanhua Chemical Group Co. Ltd. Wanhua Chemical Group Co., Ltd. is a company based in China that is engaged in distributing and manufacturing chemical products worldwide. It's in the top 500 enterprises in China with a market capitalization of 391.055 Billion CNY. Its activities cover polyurethane industrial clusters such as MDI, TDI, polyether polyols, petrochemical industrial clusters such as acrylic acid and esters, as well as propylene oxide, water-based PUD, fine chemical industrial clusters such as PA emulsion, ADI series, rubber, and plastics. It has five production bases in Yantai, Ningbo, Sichuan, Fujian, and Hungary.

Asian-minded businesses, like other foreign and domestic businesses, have realized that their environment and society expect a higher level of attention and support from them while improving quality and standard. Companies in turn have begun to develop their corporate social responsibility plans for social development and increase their profits. 
This article's aim is to introduce the non-exclusive list of corporate social responsibility of two sites of Wanhua Chemical Group Co. Ltd. (Yantai and Kazincbarcika). In order to do this, a literature review was done on the matter of social development and corporate social responsibility from both Western and Chinese researchers. As a follow-up of the two, the thoughts and teachings of Confucius are put into focus to show the unique ideology about responsibility and the expectation of society in China. Then, a brief historical background of the Wanhua Chemical Group Co. Ltd. the site in Yantai is introduced together with its standards, goals, recognitions, and achievements in CSR. Next, the predecessor of Wanhua-BorsodChem is presented before the acquisition and the special relationship between the cities of Kazincbarcika and Berente, where the Wanhua-BorsodChem is located. Additionally, the goals and aims of Wanhua-BorsodChem is looked at in relation of its CSR with special focus on its support of epidemic prevention.

\section{The concept of social development}

Researchers have been defining the meaning of social development and its existence, or even denying its existence, for decades or even centuries. The definition of the concept also encounters difficulties because both society and development itself are two complex concepts and carry many meanings as well as variations. The word development means progress, and advancement.

If we base the meaning on Arthur James Todd's (Todd, 1934) theory of development and place the human history is divided into time intervals on a clock structure, cyclically the society shows some kind of progress. Peter F. Drucker (1992) also agrees with this theory, stating: "Every few hundred years throughout Western history, a sharp transformation has occurred. In a matter of decades, society altogether rearranges itself-its world view, its basic values, its social and political structures, its arts, its key institutions. Fifty years later a new world exists." Many researchers, on the other hand, reject the notion of social development because its measurement is problematic and because of the cyclicality of events and happenings, they do not believe that society is moving in a positive direction, so they use it as 'social change' or 'social innovation'.

In its annual reports on human development published since 1990, the United Nations Development Program (UNDP) articulates social development as follows:

"Human development is a process of enlarging people's choices. The most critical of these wideranging choices are to live a long and healthy life, to be educated, and to have access to resources needed for a decent standard of living. Additional choices include political freedom, guaranteed human rights, and personal self-respect." - that is, human development is a process of increasing people's choices, the most important of which are long, healthy lives, education, and the resources needed for a decent standard of living, as well as additional opportunities including political freedom, guaranteed human rights and personal respect, Development Report (1990).

Pol and Ville (Pol and Ville, 2009) stated that “'Social innovation' seeks new answers to social problems by: identifying and delivering new services that improve the quality of life of individuals and communities; identifying and implementing new labor market integration processes, new competencies, new jobs, and new forms of participation, as diverse elements that each contribute to improving the position of individuals in the workforce. There are plenty of examples that fit well with this operational definition: some innovations that promote better education, better environmental quality, and longer life expectancy." In their analysis, Pol and Ville (Pol and Ville, 2009) also state that the concept of social innovation is inextricably linked to 'quality of life' and divides it into micro (individual) and macro (community) depending on the range of choices available. They also articulate why the concept of social 
innovation and research can be considered almost insignificant concerning business innovation because not all business innovations have a social impact, only not all are positive in the long run, citing cigarette production as an "undesirable" innovation.

According to Caulier-Grice, J., Davies, A., Patrick, R., \& Norman, W. (Caulier-Grice et al., 2012), social innovation occurs at multiple levels and scales of these incremental (product and service-focused), institutional (market-focused) and confusing (monitoring the political or social levels).

In Hungary, as in other countries, there is no uniformly used and accepted definition of the concept of social development. Other synonyms of local researchers, such as research and study in the form of social innovation and sustainable development, are typical. These analyzes differ in the number of indicators and their proposals for development and innovation. The University of Miskolc has several researchers dealing with the meaning, definition, and analysis of the concept, so the Conference Publication published on the occasion of the 30th anniversary of the start of the economics training also includes articles dealing with social innovation in a separate section.

The Conference Publication analyzes and defines social innovation from several perspectives, of which (Nemes and Varga, 2015) argues that "social innovation is a new approach, paradigm, product, process, practice that differs from the previous practice. it aims to solve emerging problems and needs while creating new values, attitudes, new social relationships, and possibly new structures" (Nemes and Varga, 2015). "Social innovation is a process that enhances the well-being of the community and helps address societal challenges." (Balaton and Varga, 2017) - that is, the creation of some kind of positive advancement and problem-solving opportunities, for which both social groups and individuals are given a choice to exploit. Among these researches, György Kocziszky and colleagues (Kocziszky et al., 2015) deal with the presentation and definition of the concept of social innovation, its measurement, and the social innovation potential of Borsod-Abaúj-Zemplén county. In the course of the analysis, the indicators of social innovation and the relationship between them are examined, and based on these, input and output indicators are distinguished. Nine indicators are listed among the four input factors they assume (institutional system, site factors, human conditions, activity). There are also thirteen indicators for the four output factors (economic, cultural, social, health). In addition to defining impact indicators and exploring the logical relationship between input-output indicators, an important distinction is made to define the concept of well-being and to separate it from well-being. Highlighting this plays an important role in the existence and further development of different development indices because by including various indicators we can assume that the GDP of a country or territory is not in line with the happiness, well-being, and social development of the local population. (Kocziszky et al., 2015)

In Chinese, society is the equivalent of the word 'shènuì' (社会), of which the character 'shè' (社) means society, group, organization, agency, and the god of the earth, and the character 'huì' (会) means chance, encounter, includes a grouping and a company. The word 'fāzhăn' (发展), however, expresses development, growth, expansion. Like other languages, several synonyms for the term social development have emerged in Chinese, such as social progress 'shèhuì jìnbù' (社会进步), social change 'shèhuì biànhuà' (社会变化), social progress 'shèhuì jìnchéng' (社会进程) and social innovation 'shèhuì chuàngxīn' (社会创新).

The Economic Development Plan issued by the Government of the People's Republic of China every five years also regularly includes proposals for social development and targeted measures. The first fiveyear plan was launched in 1953, and in 2020 the Chinese government began its 14th five-year plan, the overarching title of which is the People's Republic of China's five-year plan for national economic and 
social development. The 14th Five-Year Plan makes 12 main proposals for the country's economic and social development(中华人民共和国国民经济和社会发展第十四个五年规划和2035年远景目标纲 要):

- Adhere to the fundamental position of innovation in the overall situation of China's modernization momentum

- Accelerate the development of a modern industrial system and promote the optimization and modernization of the economic system

- Creating a strong domestic market, building a new development pattern

- Comprehensive deepening of reforms and building a high-level socialist market economy system

- Prioritizing the development of agricultural and rural areas, revitalization of the countryside

- Optimize land and space layout, promote coordinated regional development and new urbanization

- Developing cultural enterprises and cultural industries and improving the country's cultural "soft power"

- Promoting green development, promoting the harmonious coexistence of man and nature

- Ensuring a high level of openness to the outside world and opening up new opportunities for mutually beneficial collaborations

- Improve people's quality of life and raise the level of social construction

- Coordinating development and security to build a higher level of secure China

- Accelerate the modernization of national defense and the military, and achieve the unification of a rich country and a strong military

\section{Corporate Social Responsibility}

The concept of Corporate Social Responsibility (CSR) is defined and interpreted in many ways around the world. Several international organizations have tried to define the concept over the years. The first appearance of the subject in America can be traced back to the 1950s to Howard Bowen's 1953 book. (Bowen, 1953) believed that if business people in companies take social goals into account in their decision-making, it has several benefits for both economic and social development.

Based on the summary of Klára Katona (Katona, 2019), Joe Hart and Hans Jonas also examined corporate social responsibility. Joe Hart identified four aspects: task responsibility, causal responsibility, duty responsibility, and ability-based / moral responsibility. Hans Jonas distinguished two aspects but did not distinguish between the contractual and natural liability of companies.

In the 1990s, Archie Carroll (Carroll, 1991) rethought the theme and system of corporate social responsibility and created a pyramid that, like Hart, included four categories: corporate economic responsibility, legal responsibility, ethical responsibility, and philanthropic responsibility. Carroll assumed that this the basis of a company`s CSR is of exterior necessity and requirements.

Arguably the most referenced definition in Europe is from European Commission's Green Paper: "CSR is an approach whereby companies integrate environmental and social considerations into their business activities voluntarily and with stakeholders. their relationship." (European Commission, 2001, p. 6)

The famous Nobel Prize-winning economist Milton Friedman (Friedman, 1970) also dealt extensively with corporate social responsibility, but as a critical thinker in his article "The Social Responsibility of Business is to Increase Its Profit" he argued that companies then make the biggest favor to society if they focus on making a profit. Like Europe and the United States, the growing 
influence of foreign companies and investment began to spread the demand for corporate responsibility in China in the 1990s.



Figure 1. Carroll's pyramid model of CSR

Source: Carroll, A. B. (1991)

Zsuzsanna Géring (Géring, 2018) in her article differentiates three types of CSR: CSR $_{1}$ meaning corporate social responsibility; $\mathrm{CSR}_{2}$ that is corporate social responsiveness; and $\mathrm{CSR}_{3}$ which is corporate social rectitude. In her literature analysis she argues with companies becoming corporate citizens and with the weakening of nation states they have to take action and more responsibility. Géring also accepts the ideas of Polányi that companies are embedded into their surroundings, that is they have impact on the economy, society, and politics. (Géring, 2018) notes that according to Martin Parker and his colleagues (Parker et al., 2014) companies are always active actors of the society, cannot be decided whether a company strategy is either right or wrong, and that a company always has direct impact on the surrounding society, politics and economy.

\section{Confucian leadership - CSR with Chinese characteristics}

Confucius (551 BC - 479 BC) is a well-known Chinese social philosopher and thinker who had several students and followers during his time. His teachings and conversations have been written down by his students and started to gain popularity and recognition from the second half of the Han Dynasty, when Emperor WU (156 BC - 87 BC) created a state based on Confucius' ideas out of China. The Four Books (The Great Learning, Analects, Mencius and The Doctrine of the Mean) and the Five Classics (Book of Documents, Book of Odes, Book of Rites, Book of Changes and Spring and Autumn Annals) give the basic foundation of both old and New Confucianism.

Confucius divided humanity into two groups based on the inner characteristics of men and not on their wealth. These two groups were the noble people '君子' and the common people '小从' According to Confucius: “君子喻于义，小人喻于利” (Analects of Confucius) which means the common people's most important drive is profit and wealth, while noble people have a better understanding of morality, that is what is right and what is wrong to do. "If the leader acts properly, the common people will obey him without being ordered to; if the leader does not act properly, the common people will not obey him even after repeated injunctions." (Analects of Confucius) As for this, it was believed by him that only noble people can become great leaders or managers of a companies because they understand their responsibility not only towards the economy, to gain profit, but also to their employees, the society, and 
the nature. Uprightness is one of the key characteristics “荷正其身矣、於從政乎何有 不能正其身、如正人何” (Analects of Confucius) that is to say, sustainability of a company is connected to the correctness of an enterprise culture and its' managers' behavior, because only by being upright can make things right, and manage the company well.

Confucian ideas also promote the concept of harmonious society and not only business leaders but government officials base their strategies on it by creating the 'one' such as the 'One Belt, One Road' and the 'One World, One Dream' during the Beijing Olympic Games, or the reoccurring topic of 'One World, One Family' during the Chinese Bridge Competition held for foreign Chinese language learners. This concept interrelates with the so-called Panda Diplomacy and the ideas behind China's Peaceful Development. $\mathrm{Li}(\mathrm{Li}, 2008)$ also seeks to show the characteristics of Confucian-style leadership by portraying a peaceful, patient and hardworking person whose aim is to become a role-model for their company by constantly pursuing a better self.

After the Millennium, more and more companies, institutions, non-governmental organizations, and government agencies began to engage in CSR research, and finally, in 2006, the expectation of companies was enshrined in law. Article 14 of the Company Law of the People's Republic of China states "A company must, when engaging in business activities, abide by laws, observe professional ethics, strengthen the construction of socialist culture and ideology and accept supervision of the government and the public. The legitimate rights and interests of companies shall be protected by law and shall be inviolable."

Ren Yuling (Ren, 2007), Vice President of the 5th China National Democratic Construction Association of Guangxi Zhuang Autonomous Region), suggested that Chinese corporate social responsibility standards should be based on the following eight criteria:

Table 1. Basic pillars of CSR standards Source: "China's Foreign Investment", 2007, Issue 5 (Own edit)

\begin{tabular}{|l|l|}
\hline honesty & $\begin{array}{l}\text { Ensuring the authenticity of the products and } \\
\text { selling them at a fair price. }\end{array}$ \\
\hline scientific progress and responsible tax payment & $\begin{array}{l}\text { Businesses aim for responsible tax payment } \\
\text { because that is the only way to achieve } \\
\text { development and profitability. }\end{array}$ \\
\hline sustainable development & $\begin{array}{l}\text { The degree of development of enterprises must } \\
\text { be compatible with the number of resources and } \\
\text { efforts must be made to conserve them. }\end{array}$ \\
\hline environmental protection & $\begin{array}{l}\text { Companies must take responsibility for } \\
\text { protecting the environment to protect and make } \\
\text { the world livable. }\end{array}$ \\
\hline cultural construction & $\begin{array}{l}\text { Companies need to help the state make health, } \\
\text { educational and cultural developments. }\end{array}$ \\
\hline charity development & $\begin{array}{l}\text { Poverty alleviation in society, rural } \\
\text { development. }\end{array}$ \\
\hline protection of the health of employees & $\begin{array}{l}\text { Maintaining the health of workers and ensuring } \\
\text { an adequate income. }\end{array}$ \\
\hline development of science and technology & $\begin{array}{l}\text { Incorporation and development of imported } \\
\text { knowledge and technology, protection of } \\
\text { intellectual property rights. }\end{array}$ \\
\hline
\end{tabular}


Based on Wang Hui (Wang, 2005), "SA8000", which both the Yantai Center and BorsodChemWanhua include in their corporate social responsibility reports, is a social responsibility standard that stands for Social Accountability 8000, the world's first international ethical standard. It aims to ensure that products supplied by suppliers meet the requirements of social responsibility standards. The SA8000 standard can be applied to companies of all sizes anywhere in the world. It is based on the ISO9000 quality management system and the ISO14000 environmental management system, which is a set of international standards that can be verified by third-party certification agencies. The SA8000 standard examines and addresses issues such as child labor; forced labor; health and safety; freedom of association and the right to bargain collectively; discrimination; punitive measures; working hours; payment; management system.

\section{Description of the Wanhua Group}

Wanhua Chemical Group Co., Ltd. is a new worldwide chemicals company. Its activities cover polyurethane industrial clusters such as MDI, TDI, polyether polyols, petrochemical industrial clusters such as acrylic acid and esters, as well as propylene oxide, water-based PUD, fine chemical industrial clusters such as PA emulsion, ADI series, rubber, and plastics. The industries served are mainly residential and home furnishings, sports and leisure, automotive, construction, electronics, personal care, and green energy. The main profile of the group is MDI and TDI production. It has five production bases in Yantai, Ningbo, Sichuan, Fujian, and Hungary, and supports factories in many locations, forming a strong manufacturing and operating network; in addition, Yantai, Ningbo, Beijing, Shanghai, North America, and Europe have completed six R\&D centers and set up subsidiaries and offices in more than ten countries and regions, including Europe, the United States, and Japan.

\subsection{Yantai Wanhua Polyurethane Co.}

In 1978, after permission from the State Planning Commission and the Project Construction Committee, construction began on a new synthetic leather factory in Yantai City, Shandong Province. It became the first PU (polyurethane) base in China. As the sixth five-year plan to strengthen China's economic growth, production and development were realized with an investment of RMB 460 million (> USD 65 million) to continue building the plant. In 1989, the Yantai Synthetic Leather Factory has renamed the Yantai Synthetic General Leather Factory, and the original isocyanate production division grew into an Isocyanate Industry Factory. In 1995, the synthetic manufactures were renamed Yantai Synthetic Leather Group, and finally in 1998, after a share reform, Yantai Wanhua Polyurethane Co., Ltd. was established.

In 2001, Wanhua was listed on the Shanghai Stock Exchange. As of April 30, 2020, the highest was CNY 45.45 and its total market value was CNY 141.289 billion.

Wanhua is among the world's largest producers of methylene diphenyl diisocyanate (MDI) and Europe's largest supplier of TDI. The world's best producers of methylene diphenyl diisocyanate (MDI). It has six manufacturing and business centers in China, including Yantai, Chengdu, Ningbo, Zhuhai, Beijing, and Shanghai, and has set up branches around the world, one of which has become its production base in Hungary. Wanhua Chemical Group Co., Ltd. acquired BorsodChem in Kazincbarcika, Hungary, which was an important part of the company's global strategy. It currently has approximately 15,000 employees worldwide.

In 2019, it was included in the top 500 Chinese enterprises. Wanhua's net assets were CNY 38 billion in 2018 and reached CNY 42 billion by the end of 2019 . 


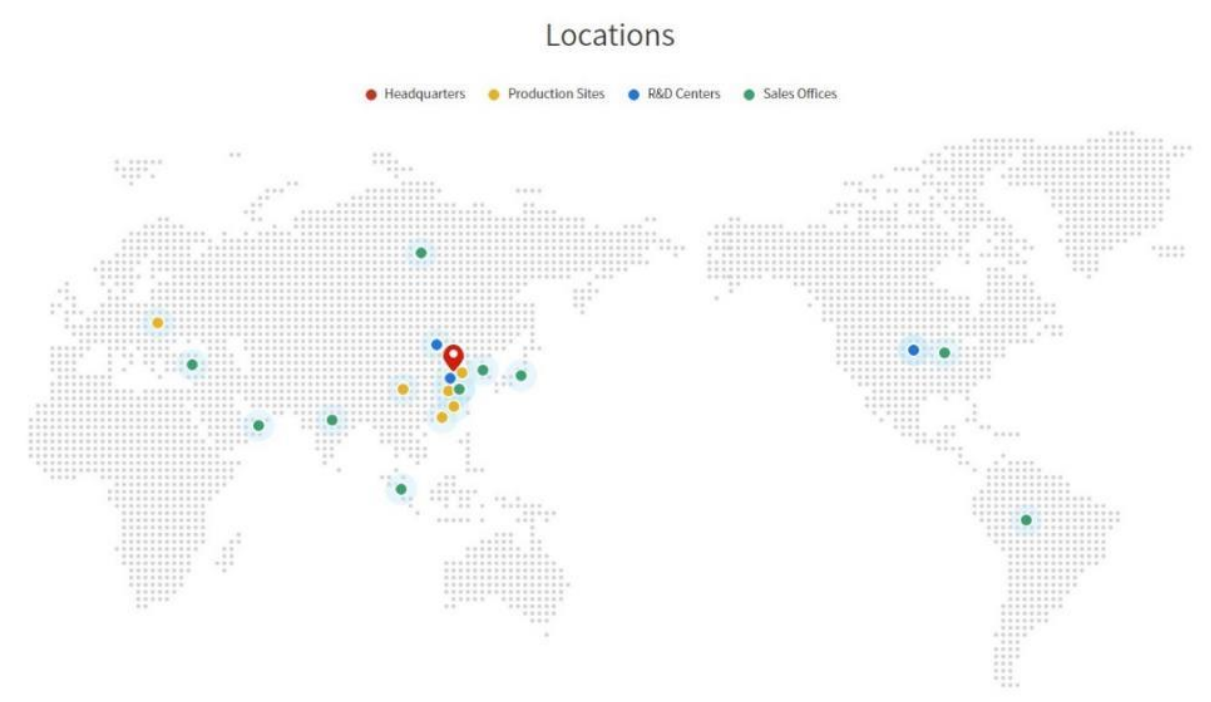

Figure 2. Global distribution of Wanhua Chemical Group Co., Ltd.

Source: Wanhua Chemical Group Co., Ltd. website. https://www.whchem.com/column/79/

\subsubsection{Yantai Wanhua Polyurethane Co. Social Responsibility}

Yantai's main goal and motto have been that chemistry improves life. To this end, it prepares an information report on the company's social responsibility each year. According to the 2019 report, they also chose a topic for their responsibility, namely the improvement of safety management. They see a responsibility to ensure the safety, health, environment, and conservation of resources for employees, customers, and communities. The company has also set up a special committee to make and implement these decisions.

First, the report discusses the importance of innovation developments as this ensures the competitiveness of the company. They want to create products that also serve the development of society, so they track foreign developments and strive for higher quality. It supports research and development with R\&D centers established in many parts of the world. It highlights in a separate section the right and protection of intellectual property and its respect both inside and outside the company.

As a second category, it draws attention to the importance of environmental protection by following the life cycle of products (product, flue gas, noise, sewage, waste, chemical treatment) with an HSE department. In addition to waste management, it also takes into account energy efficiency, takes into account climate change, and regulates greenhouse gas emissions.

As a third point, it designates a safe Wanhua and follows the example of foreign companies such as General Motors because the company strives to prevent any accidents, injuries, and emissions. As a result of this effort, the company regularly conducts safety training and installs ventilation and dust extraction systems within the plants. The Yantai and Ningbo production bases have 140 million CNY in factory safety, so the Yantai factory has 13 fire trucks and 5 fire robots, as well as 80 full-time, 38 regular, and 574 part-time firefighters.

In addition to maintaining and maintaining plant safety, the company also pays attention to product safety through toxicological testing during and after the manufacturing process, particularly when testing new products and processes. The process does not end when the product is completed, but the 
shipment is also done with the utmost care, so logistics security is included as the fourth point in the report.

The fifth section prioritizes the prevention, monitoring, and control necessary for proper functioning, as well as zero tolerance for abuse and fraud.

The sixth point is Wanhua's integrity, mutual assistance, and cooperation, which encourages the sustainable development of the supply chain and seeks to create a win-win situation as the raw materials Wanhua uses come from all over the world.

As a seventh category, it displays a collaboration with external organizations and an evaluation of their feedback, which will help the company take on its future responsibilities. In addition, he writes about knowledge-based employment and equal opportunities for workers regardless of gender or racial origin. To achieve a welfare society, continuous wage developments are taking place, with the introduction of various benefits and discounts for employees. For the sake of workers, various unions and associations have been set up to help their troubled peers who are facing urgent difficulties. It pays attention to the continuous training of employees and the nurturing of talent and the embrace of talented young people with the Wanhua Scholarship. It assists in the local construction and development of street lamps, roads, sports, and fitness facilities. It participates in the government's nest-building campaign to support young people and, in cooperation with universities and organizations, launches innovative tenders.

In 2008, a magnitude of 8.0 earthquake hit Wenchuan (Sichuan) Wanhua donated 2 million CNY, and invested 5 million CNY to build fraternity school in Mianyang (Sichuan).

Table 2. Wanhua Chemical Group Co., Ltd. Recognitions for Social Development. Source: Wanhua Chemical Group Co., Ltd. website. https://www.whchem.com/column/79/

\begin{tabular}{|l|l|}
\hline Year & Recognition \\
\hline 2019 & $\begin{array}{l}\text { Together for Sustainability (TfS) joins as the first Chinese member of the organization of } \\
\text { chemical companies. }\end{array}$ \\
\hline 2018 & $\begin{array}{l}\text { European Union EcoVadis global corporate social responsibility assessment silver } \\
\text { certification } \\
\text { Social Responsibility Contribution in China - Gold Award }\end{array}$ \\
\hline 2017 & Social Responsibility Contribution in China - Gold Award \\
\hline
\end{tabular}

Urbanization in China is a key issue, because for the sake of better life more and more people from rural parts of China migrate to bigger cities. This process created the problem of the so-called left/behind children. As of 2018 there were about 6.97 million left-behind children reported all through China. In order to help these children living in poverty from 2014, Wanhua started a public welfare fund-raising activity in 10 villages.

In 2015 Wanhua launched a program called "Magic Laboratory" in order to educate children of all ages to introduce them the wonders of chemistry through experiments addressing schools all around China, especially at the remote areas.

Wanhua Chemical actively assumes social responsibility and improves the quality of life in the areas by helping poor areas repair houses, renovate roads, and donate daily necessities. In 2020, Wanhua Chemical invested more than 1 million CNY in helping communities.

In 2020, the COVID-19 epidemic broke out, Wanhua Chemical took the prevention and control of the epidemic as the current priority. The company established an epidemic emergency work team, strengthened research and deployment. Domestically, the company took initiative to be a corporate 
citizen to support the prevention and control of the epidemic area in Hubei and the local epidemic in Yantai. Wanhua Chemical donated more than 6 million CNY in materials in China. Among them, donated 5 million CNY to the Hubei Red Cross Society, purchased 10,000 sets of medical protective clothing, donated to Shandong Province, Hubei Province, Yantai City and other relevant departments, and applied to become a reserve unit of disinfectant in Yantai City. Overseas, a total of about 3.5 million $\mathrm{CNY}$ was donated in materials.

\subsection{Wanhua-BorsodChem}

The history of Wanhua-BorsodChem's predecessor dates back more than 7 decades, starting with the 1949 construction of the Borsod Chemical Plant (BVK). BVK was established in 1954 by the merger of the Borsod Industrial Trust, the Borsod Coke Works, and the Sajómenti Chemical Works.

Based on Sikos (Sikos, 1995), I have summarized the history of the company over the years. Nitrogenbased fertilizers were produced as the first product useful in agriculture. The coke-based plant has undergone continuous development and expansion and has switched to ground-based production. Later, in the 1960s, the PVC factory of Berentei Chemical Works was merged with the construction of a PVC factory. Subsequently, due to the growing demand for PVC, in 1965 it became necessary to expand the PVC factory as well as to build a caprolactam plant.

The next stage of development can be considered when an olefin production and investment program was launched in the 1970s, for which ethylene is supplied from the Tisza Chemical Plant. Based on Kazincbarcika-Zsákutca vagy útelágazás? (Sikos, 1995), BVK was setting up several plants nationwide (Szekszárd, Tatabánya, Miskolc) as a result of increased demand and increasing volume production. The number of employees at BVK has almost doubled in the next twenty years. As a result of the deteriorating external and internal situation, the company tried various domestic economic associations. In the hope of difficulties and sustainable operation of the company, it was transformed in 1991 into BorsodChem Rt. It was listed on the London Stock Exchange in 1996 but was unfortunately delisted in 2006. Finally, following the 2011 acquisition by the Wanhua Group, the Wanhua Group re-listed BorsodChem in 2019. According to the last statistics from OPTEN currently there are 2564 emloyees working at the Wanhua-BorsodChem.

\subsubsection{Berente and Kazincbarcika}

Berente, located next to Kazincbarcika, was declared a separate village by the locals in 1996 through a referendum. According to a 1954 administrative boundary, 2/3 of the buildings and plants of the Wanhua-BorsodChem factory were built in Berente and the other 1/3 in Kazincbarcika. According to Veresné dr. Zsuzsanna Jakab (2005), this independence triggered a very long, never-ending legal debate, as it also affected the revenue sources of the two cities due to the significant business tax of WanhuaBorsodChem. During the seven years of litigation, the court always referred to and accepted the 1954 settlement boundaries, so in 2007 the two cities finally managed to reach an out-of-court settlement. According to the new agreement, the municipality of Berente has undertaken to help Kazincbarcika for the next 30 years, and half of the business tax on the newly built plants will enrich Kazincbarcika's revenue.

Inferring from its annual income, Wanhua-BorsodChem is required to pay a business tax of the order of millions, which is shared by Kazincbarcika and Berente. Regarding Berente, where no other larger company is operating and where $2 / 3$ of the area is made up of Wanhua-BorsodChem plants, the figure below shows the last 6 years based on the local government budget. 
Development of the business tax

revenue of Berente in 2014-2020

(HUF)

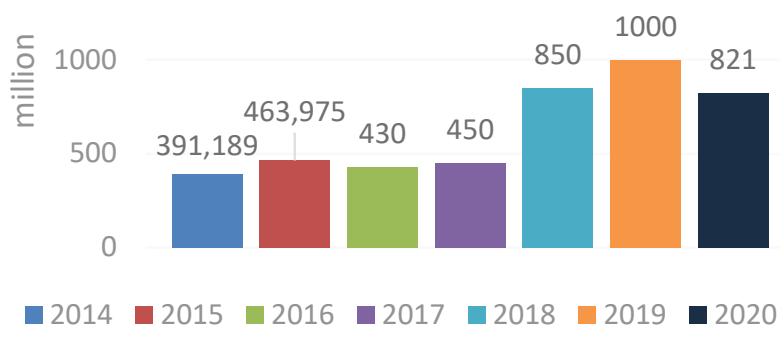

Figure 3. Development of the business tax revenue of of Berente in 2014-2020 Source: Annual budgets of the municipality of Berente. Own editing.

The corporate tax paid by Wanhua-BorsodChem also supports several spectacle team sports in Kazincbarcika, such as water polo, swimming, volleyball, football, hockey, and handball. As part of these subsidies, the Municipality of Kazincbarcika began to renovate or in many cases newly build various sports facilities. The cornerstone of the ice rink and water and recreation center was laid in 2019, and in 2020 the construction processes of the volleyball center also began.

\subsubsection{Wanhua-BorsodChem's Social Responsibility}

Based on its 2018 Sustainability Report, Wanhua-BorsodChem has set five key goals:

- Poverty eradication

- Eliminate hunger

- Health and Well-being

- Quality education

- Gender equality

According to the report, Wanhua-BorsodChem prioritizes the employment of highly skilled and highly knowledgeable individuals. Based on its own Code of Ethics and SA 8000: 2014, it also pays close attention to the gender ratio within the company and rejects discrimination on the grounds of race, gender, religion, and other grounds. In 2017, Wanhua-BorsodChem won the "Responsible Employer of the Year" award. In addition, it prioritizes the retention of its existing fixed-term employees through an annual employee satisfaction survey, based on which Wanhua-BorsodChem is trying to change its strategy. He also organized a mentor program to allow employees with extraordinary knowledge in the run-up to retirement to pass on their knowledge to the younger generation. Exit interviews are also conducted with employees who may leave, based on which the company's employment policy is also formed.

Wanhua-BorsodChem carries out activities in several ways (career guidance, internships, chemical engineering training, dual training, scholarship program) to improve education and replace and secure employees with the appropriate chemical qualifications. In addition to the school system, the company has also launched retraining and induction programs, and many employees have the opportunity to attend courses at Wanhua's Chinese sites. 
To preserve and protect the health of its employees, the company provides health insurance packages that give them free access to private health services. Due to the company's occupational safety regulations and because it is mostly necessary for employees to work with hazardous chemicals, the factory performs numerous and frequent screening tests. Within this framework, the company is also a believer in a healthy lifestyle, thus providing free sports opportunities. To protect workers and residents, many safety systems have been built and the factory has its fire department. The company also considers the safety of customers to be important, so products are provided with descriptive data sheets written in the language of the customer, and important attention is paid to the protection of the data of both customers and employees.

Part of Wanhua-BorsodChem's social commitment is to develop and catch up with local settlements, in part by offering a corporate tax.

They support environmental projects, collect collections (Nagybarca Children's Home) and organize events (Color Festival, Concert, Confucius Institute Programs), and support foundations (Kazincbarcika Association for the Disabled, Medicopter Foundation, National Ambulance Foundation). They also consider it important to inform the local population about the changes affecting the factory, therefore they hold regular public forums, to which the residents of Kazincbarcika and Berente are expected.

Wanhua-BorsodChem is an excellent supporter of the University of Miskolc in the fields of education, cooperation, and sports activities. The university circle hall has gained its renewed form with the support of the company's TAO and, in addition, it even supports visual team sports, which has exceeded 600 million HUF in the last six years. In the field of innovation, it helped the university to win billions of forints in joint R\&D tenders. The special cooperation is also facilitated by the Confucius Institute of the University, established by the University of Miskolc, Wanhua-BorsodChem, and the Beijing University of Chemical Industry. Wanhua-BorsodChem won the University of Miskolc's Outstanding Sponsorship Award in 2019 as a joint thanks for the grants, dual training, BorsodChem scholarship, and the launch of chemical engineering training.

Table 3. Wanhua-BorsodChem Recognitions for Social Development. Source: Wanhua-BorsodChem website. https://karrier.borsodchem.eu/dijaink

\begin{tabular}{|l|l|}
\hline Year & Recognition \\
\hline 2021 & $\begin{array}{l}\text { EcoVadis Platina Medal for sustainability activities(among the top 1\% of chemical } \\
\text { companies globally) }\end{array}$ \\
\hline 2020 & Loveable jobs \\
\hline 2019 & $\begin{array}{l}\text { Factory of the Year 2019 (Most effective production support processes, energy } \\
\text { efficiency, complex winner over HUF 10 billion annual net sales category) } \\
\text { - Benefit Prize 2019 - Audience Award for Happy Employees } \\
\text { - Family-Friendly Company 2019 } \\
\text { - University of Miskolc's Highlighted Sponsor 2019 }\end{array}$ \\
\hline 2017 & Responsible Employer of the Year 2017 \\
\hline
\end{tabular}

Support is also reciprocal at the government level. In 2020, Wanhua-BorsodChem announced a $€$ 35.5 million investment to set up a concentrated nitric acid plant to increase energy efficiency and import procurement. As a result of the investment, the Hungarian government also offered its support.

Due to the epidemic situation in Hungary in 2020, Wanhua-BorsodChem continued to support local hospitals and, being a large chemical company, offered more than 25,000 liters of hypo for disinfection to local institutions and organizations alike. 
To support the cause of epidemic prevention and control in 2020, Wanhua-BorsodChem donated a total of 15 million HUF to the BAZ State Hospital and University Education Hospital, and 5 million HUF to the Kazincbarcika Municipal Hospital. In addition, Wanhua-BorsodChem also donated 10,000 masks and nearly 10,000 liters of self-produced disinfectant to health and social care institutions and surrounding cities. In addition, Wanhua's downstream customers provided 30,000 masks, 400 sets of protective clothing and 400 goggles for free.

\section{Summary}

The present study examined the concepts of corporate social responsibility and social development from the perspective of the Chinese-owned Wanhua-BorsodChem and the parent company of the Wanhua Group operating in Hungary through the teachings of Confucius. Wanhua-BorsodChem's most frequently cited responsibilities are knowledge-based employment, security, and energy efficiency. Referring to these, the company not only supports but also undertakes specialized further training and retraining to be able to provide suitable employees for the company. Knowledge-based employment is associated with all condemnation of discrimination, which is particularly important for a company with foreign interest and management, and the provision of adequate and evolving wages. Creating security has become especially important nowadays, due to the epidemic situation, there has been a decline in both production and foreign exchanges and cooperation, and it has become important to protect our health. The Yantai plant shares the importance of safety issues and prioritizes the development of safety systems to protect the health of employees, the public, and customers.

Through the example of several other companies, Wanhua-BorsodChem has also sought to help organizations and hospitals and donate disinfectants. As a chemical company, the local population is very concerned about the protection of the environment and the sustainability of the surrounding resources, as well as safety, so the company holds regular open information and strives to comply with European standards.

From the case of Wanhua, the increasing will of taking social responsibility can be seen. As Confucius said the kindness and humanity is in all people, we just have to take a closer look. For the sake of society and the global pressure, more and more companies are starting to take their share from the burden of the world and give back to the society. All companies have both direct and indirect impact on their surroundings because they are economically, socially and politically embedded. It takes three, the 'partnership' of the local government, society and the company itself to set boundaries and request of the amount of responsibility desired.

\section{References}

[1] Analects of Confucius. (2010). Fujian Education Press.

[2] Balaton, K., and Varga, K.: Társadalmi innováció és versenyképesség - szakirodalmi áttekintés az elméleti munkák alapján, (Social innovation and competitiveness - literature review based on theoretical work.), 2017 „Mérleg és Kihívások” X. Nemzetközi Tudományos Konferencia, Miskolc, 2017. október 17-18., pp. 35-47.

[3] Bowen, H. R. (1953). Social responsibilities of the businessman. Harper \& Row, New York.

[4] Buchowicz, B. (1990). Cultural transition and attitudes change. Journal of General Management. https://doi.org/10.1177/030630709001500404

[5] Caulier-Grice, J., Davies, A., Patrick, R., \& Norman, W.: Defining Social Innovation. A deliverable of the project: "The theoretical, empirical and policy foundations for building social 
innovation in Europe" (TEPSIE), $20127^{\text {th }}$ Framework Programme. Brussels: European Commission, DG Research.

[6] Carroll, A. B. (1991). The pyramid of corporate social responsibility: Toward the moral management of organizational stakeholders. Business Horizons, 34, 39-48. https://doi.org/10.1016/0007-6813(91)90005-G

[7] Company Law of the People's Republic of China. Database of Laws and Regulations. http://www.npc.gov.cn/zgrdw/englishnpc/Law/2007-12/12/content_1383787.htm

[8] Géring, Zs. (2018). A vállalati társadalmi felelősségvállalás kritikai megközelítései. (Critical approaches to corporate social responsibility.) Replika, 2018(1-2), 106-107. https://doi.org/10.32564/106-107.4

[9] Green paper - Promoting a European framework for Corporate Social Responsibility. Commission of the European Communities. Brussels, 18.7.2001 COM (2001) 366 final

[10] Human Development Report (1990). Concept and Measurement of Human Development http://hdr.undp.org/en/humandev [Downloaded: 2020.11.2.]

[11] Katona, K. (2019). A vállalati társadalmi felelösségvállalás kritikája a katolikus egyház társadalmi tanításának tükrében. (A critique of corporate social responsibility in the light of the social teaching of the Catholic Church.) Iustum Aequum Salutare, XV. 2019. 4., 23-46. Pázmány Péter Katolikus Egyetem, Jog- és Államtudományi Kar.

[12] Kocziszky, Gy. (2001). Területfejlesztés gazdaságtana. (Economics of regional development). Miskolc

[13] Kocziszky, Gy., and Benedek, J. (2013). Bevezetés a regionális politikába. (Introduction to regional policy.) Miskolc, Magyarország: Miskolci Egyetemi Kiadó, 205 p.

[14] Kocziszky, Gy., et al.: Társadalmi innováció mérésének sajátosságai, (Peculiarities of measuring social innovation.), 2015 „Mérleg és Kihívások” IX. Nemzetközi Tudományos Konferencia, Miskolc, 2015. október 15-16., pp. 288-302.

[15] Kocziszky, Gy., et al. (2017). A társadalmi innováció vizsgálatának tapasztalatai és fejlesztési lehetőségei. (Experiences and development opportunities of social innovation research.) Vezetéstudomány - Budapest Management Review, 48(6-7). 15-19. https://doi.org/10.14267/VEZTUD.2017.06.02 [Downloaded: 2020.11.19.]

[16] Communique of 5th plenary session of 19th CPC Central Committee. CCTV.com https://news.cctv.com/2020/10/29/ARTIV6Jto3BFezK1E14F0zL3201029.shtml?spm=C96370.

PsikHJQ1ICOX.Em32AuyOHUeL.12 [Downloaded: 2020.10.29.]

[17] Kulcsár, A. (2015). Public diplomacy and its implications to Sino-Hungarian bilateral relations. Master's Thesis: Tsinghua University.

[18] Kormányzati támogatásban részesült a Borsodchem. (Borsodchem received government support) minap.hu. 2020. November 30. Monday. 10:32., https://minap.hu/index.php/cikk/kormanyzatitamogatasban-reszesult-borsodchem

[19] Krugman, P. (1991). Increasing returns and economic geography. Journal of Political Economy, 99, 483-499. https://doi.org/10.1086/261763

[20] Krugman, P. (2003). Földrajz és kereskedelem. (Geography and trade). Nemzeti Tankönyvkiadó.

[21] Li, C. (2008). The philosophy of harmony in classical Confucianism. Philosophy Compass, 3(3), 423-35. https://doi.org/10.1111/j.1747-9991.2008.00141.x

[22] Lengyel, I. (2003). Verseny és területi fejlödés. (Competition and territorial development). Szeged, JATE Press. 
[23] Lengyel, I., and Rechnitzer J. (2004). Regionális gazdaságtan. (Regional economics). DialógCampus Kiadó, Budapest-Pécs.

[24] Lösch, A. (1940). Die räumliche Ordnung der Wirtschaft. Gustav Fischer Verlag, Tübingen.

[25] March, J. G., and Johan, P. O. (1975). The uncertainty of the past: organizational learning under ambiguity. Bergen. https://doi.org/10.1111/j.1475-6765.1975.tb00521.x

[26] Market Research Reports. World's Top Methylene Diphenyl Diisocyanate (MDI) Manufacturers. https://www.marketresearchreports.com/blog/2019/09/09/world\%E2\%80\%99s-top-methylenediphenyl-diisocyanate-mdi-manufacturers

[27] Friedman, M. (1970). The social responsibility of business is to increase its profit. The New York Times Magazine, 1970(September 13).

[28] Nemes, G., and Varga, Á. Társadalmi innováció és társadalmi tanulás a vidékfejlesztésben sikerek, problémák, dilemmák, (Social innovation and social learning in rural development successes, problems, dilemmas), 2015 „Mérleg és Kihívások” IX. Nemzetközi Tudományos Konferencia, Konferencia kiadvány, pp. 434-444.

[29] Nemes, N. J. (2009). Terek, helyek, régiók. (Areas, places, regions.) Budapest, Akadémia Kiadó.

[30] Papp, A. (1974). Ismerkedjünk Kazincbarcikával. (Let's get to know Kazincbarcika.) Kazincbarcikai Városi Könyvtár.

https://web.archive.org/web/20130331134506/http://www.egressy.hu/files/downloads/ismerked j.pdf

[31] Pol, E., and Ville, S. (2009). Social innovation: Buzz word or enduring term? The Journal of Behavioral and Experimental Economics, 38(6), 878-885.

https://doi.org/10.1016/j.socec.2009.02.011

[32] Porter, M. E. (2000). Clusters and goverment policy. Wirtschaftspolitische Blätter, 2, 144-154.

[33] Sikos, T. (1995). Kazincbarcika-Zsákutca vagy útelágazás? (Kazincbarcika-Dead end or road junction?) http://mek.oszk.hu/09000/09093/09093.pdf

[34] Ren, Y. (2007). 企业应承担的八大社会责任 (Eight social responsibilities that enterprises should bear) Foreign Investments. May, 2007.

http://www.cqvip.com/Main/Detail.aspx?id=24273236

[35] The 6th Five-Year Plan. ChinaDaily.com.cn http://www.chinadaily.com.cn/china/2012npc/2011-02/23/content_14689649.htm

[36] Todd, A. J. (1934). Theories of social progress: A critical study of the attempts to formulate the conditions of human advance. Macmillan.

[37] Varga, A. (2002). Thünen és az „Új Gazdaságföldrajz” térgazdaságtana. (Thünen and the spatial economics of "New Economic Geography".) In Barancsik, J., Oroszi, S., Varga, A. (Eds.), Tanulmánykötet Zinhober Ferenc professzor emlékére (pp. 85-98). PTE KTK, Pécs.

[38] Veresné, J. Zs. (2005). Egy „szétválás” anomáliái avagy kazincbarcika és az önállóvá váló Berente 6 éves története. (Anomalies of a "split" or Kazincbarcika and the 6-year history of Berente becoming independent.) 2005/4. Jegyzö és Közigazgatás, VII(4). HVG-ORAC Kiadó. https://jegyzo.hu/egy-szetvalas-anomaliai-avagy-kazincbarcika-es-az-onallova-valo-berente-6eves-tortenete-20054/

[39] 万华化学 (Wanhua Chemical Group Co., Ltd). http://finance.sina.com.cn/realstock/company/sh600309/nc.shtml?wm=b213

[40] 万华化学集团股份有限公司 2019 年年度报 (Wanhua Chemical Group Co., Ltd. 2019 Year Report). http://static.cninfo.com.cn/finalpage/2020-03-31/1207432775.PDF 
[41] 万华化学: 2019 年度社会责任报 (Wanhua Chemical Group Co., Ltd. 2019 Year Social Responsibility Report).

https://wenku.baidu.com/view/71cef780c3c708a1284ac850ad02de80d5d80651.html

[42] 万华化学集团股份有限公司 2020 年度社会责任报告. 烟台, 2021年（2020 Social Responsibility Report of Wanhua Chemical Group Co., Ltd. Yantai, 2021.).

[43] Wang, H. (2005). 论企业社会责任 (About Social Responsibility). Huazhong Technical University.

[44] Weber, A. (1909). Über den Standort der Industrien. J.C.B. Mohr, Tübingen.

[45] 压实互联网企业的主体责任 (Consolidate the main responsibility of Internet companies). Internet Consolidation Magazine. 2018.11.06. http://www.cac.gov.cn/201811/06/c_1123672701.htm

[46] 中华人民共和国国民经济和社会发展第十四个五年规划和 2035 年远景目标纲要. 中华人 民共和国国家发展和改革委员会. 2021 年3 月 (The Fourteenth Five-Year Plan for the National Economic and Social Development of the People's Republic of China and the Outline of Long-term Goals for 2035. National Development and Reform Commission. March, 2021). https://www.ndrc.gov.cn/xxgk/zcfb/ghwb/202103/P020210323538797779059.pdf

[47] 2019 中国企业500. 百度百科 (2019 Chinese Enterprise 500. Baidu Baike). https://baike.baidu.com/item/2019\%E4\%B8\%AD\%E5\%9B\%BD\%E4\%BC\%81\%E4\%B8\%9A $500 \% \mathrm{E} 5 \% \mathrm{BC} \% \mathrm{BA} / 23723573$ 